Journal of the Egyptian Society of Parasitology, Vol.43, No.1, April 2013

J. Egypt. Soc. Parasitol., 43(1), 2013: 259 - 268

\title{
GASTROINTESTINAL PARASITES AND ECTOPARASITES BIODIVER- SITY OF RATTUS RATTUS TRAPPED FROM KHAN YOUNIS AND JABALIA IN GAZA STRIP, PALESTINE \\ By
}

\author{
ADNAN IBRAHIM AL HINDI and EMAN ABU-HADDAF \\ Department of Biology Science, Faculty of Science, The Islamic University \\ of Gaza, P.O. Box, 108, Gaza, Palestine, E-mail:ahindi@iugaza.edu
}

\begin{abstract}
This study identified the zoonotic endo-parasites and ecto-parasites of Rattus rattus. A total of 41 rats of house (black) rat and Norway (brown) rat were trapped from two regions of Gaza strip. After dissection, isolated protozoa, nematodes and cestodes were identified respectively according standard keys. The results showed that prevalence of intestinal parasites among rats was 24/41 (58.5\%) and males were infected more than females. A high prevalence of protozoa was in autumn compared to other seasons. The intestinal parasites were encountered: G. lamblia 6 (14.6\%); E. histolytica/dispar 7 (17.1\%); Isospora 4 (9.8\%); Acanthocephala 1 (2.4\%); Syphacia obvelata 6 (20\%); Heligmonoides josephi 3(10\%); Strongyloides egg 1 (2.4\%); Hymenolepis diminuta 15 (36.6\%). The insects were Xenopsylla cheopis 7 (17.1\%); Polyplax spinulosa 3 (7.3\%).
\end{abstract}

Key words: Gaza, Rodents, Intestinal parasites, Ecto-parasites.

\section{Introduction}

Three rat species; Rattus rattus or black rat, $R$. norvegicus or Norway rat, and $R$. exulans or Pacific rat, as well as the house mouse, Mus musculus have been widely introduced to terrestrial environments across the planet; more than $80 \%$ of island groups have been invaded (Towns, 2009) and most insular invasions include more than one of these four species (Yom-Tov et al, 1999; Russell and Clout, 2004). All the four rodent species are voracious predators of a wide range of plants and animals, and are probably the invasive animals responsible for the greatest number of plant and animal extinctions on islands (Towns et al, 2006; Angel et al, 2009).

Various races of $R$. rattus have been imported, and are abundant in the towns of Palestine (Luke and KeithRoach, 1922). The regular environmental changes, the un-proper storage and handling of food products, the unhygienic disposal of organic products and spreading of garbage in Gaza Strip encouraged the breeding and spreading of rodents in spite of the wide range of stray cats. In Gaza strip it was reported two types of rodent (rats) Rattus rattus house (black) rat, $R$. norvegicus Norway (brown) rat of Order Rodentia as 
wild mammals (Abd Rabou, 2007). No doubt, rodents are responsible many zoonotic diseases as Toxoplasma gondii, Eimeria muris, Spironucleus muris, Giardia muris, Cryptosporidium spp., Encephalaprotitozoan cuniculi, Hepatozoan muris, Babesia muris, Yersinia pestis, Borrelia duttonii and others (Nama and Parihar, 1976; Younis et al, 1995; Claveria et al, 2005). They may also convey Nippostrongylus muris, Syphacia ob-velata, Aspiculuris tetraptera, Trichinella muris; Taenia taeniaeformis, Hymenolepis nana and $H$. diminuta. Rodents are hosts to a number of ectoparasites such as lice, mites and fleas that can transmit viral, bacterial and protozoan parasites to man and animals (Mosabah and Morsy, 2012; Morsy, 2012). The data on the prevalence of intestinal parasites of rodents are unavailable but some studies were carried out on different types of animals in Gaza (Rayyan et al, 2013).

This study aimed at the identification of the endo-parasites and ecto-parasites of the commonest domestic rodent; Rattus rattus.

\section{Materials and Methods}

The study was carried out from January 2010 to May 2011. A total of 41 rats were trapped alive from Khan Younis and Jabalia in Gaza Strip.

Rodent trapping: Baited wire box traps with front spring door type were used (Fig. 1). Baits included meat, parts of fishes, breads, tomato, cucumber and cheese. Traps were cleaned with hot water and soap every time before use. Traps were distributed indoors and outdoors of inhibited buildings just before sunset and collected next morning in separate white closed bags and immediately transported to the experimental laboratory of the Department of Biology.

The rodents were identified by species and sex (Morsy et al, 1988). Each rat was examined for the presence of ectoparasites, where in case of positive each ectoparasite was removed by adding one drop of saline on the insect and picked up added by light source. The recovered ecto-parasites were preserved with $70 \%$ ethanol and $5 \%$ glycerin for identifications using standard keys (Hoogstraal, 1958; 1965; Mazyad et al, 1999; Abd El-Halim et al, 2009).

Dissection: Rats were anaesthetized by putting the live ones in a thick transparent polythene bag that helped to observe the movement of rats. A cotton soaked in chloroform (Singla et $a l, 2008)$ was used for anaesthetizing, then the abdomen was dissected out starting from the skin region was at the end of the body end forwards to avoid intestinal destruction.

Isolation and staining of intestinal parasites: Each rat intestine was examined for the presence of cestodes and detached worms were removed to warm saline in Petri dishes. Tape worms were left in the cold saline solution to be washed and then preserved in $10 \%$ formaldehyde. Parasites or their regions including scolices and proglottids were gently removed from the host body for identification to the species level under the dissecting microscope (Jones et al, 1994). 
Isolation of Protozoa: A fecal sample was taken from each rat in a sterile cup and preserved by sodium acetate acetic formalin (SAF) to be examined later for the presence of any type of protozoa. Each preserved fecal sample was examined by X10, X40 searching for any protozoa cyst and oocysts according (WHO, 1994).

The noted round worms for each rat was taken out of the container and washed by saline solution then it was fixed by $70 \%$ ethanol. The isolated nematodes were counted by manual way, and males and females were isolated in separate containers identification (Anderson et al, 2009).
The protozoa and larvae of nematodes were photographed by Canon shot power S50 digital camera from the biology department, and the nematode by TV capture camera from the medical technology department and Canon shot power S50 digital camera.

\section{Results}

Despite the relatively few rats examined in this survey yet, several parasites were isolated. The general prevalence of intestinal parasites was 24/41 $(58.5 \%)$. The males were more infected than females. The details are shown in tables $(1,2,3,4,5 \& 6)$.

Table 1: Prevalence of intestinal parasites in R. rattus collected from Khan Younis and Jabalia in Gaza Strip $(\mathrm{n}=41)$

\begin{tabular}{|c|c|c|c|}
\hline Sex & Number examined & Number of positive & Prevalence (\%) \\
\hline Males & 26 & 17 & 65.4 \\
\hline Females & 15 & 7 & 46.7 \\
\hline
\end{tabular}

Table 2: Prevalence of intestinal parasitic infection by sex in $R$. rattus trapped from Khan Younis and Jabalia in Gaza Strip $(n=41)$

\begin{tabular}{|c|c|c|c|}
\hline Intestinal parasites class & Males $(\mathrm{n}=26) \%$ & Females $(\mathrm{n}=15) \%$ & P-value \\
\hline Protozoa & $9(34.6)$ & $3(20.0)$ & 0.266 \\
\hline Nematodes & $7(26.9)$ & $3(20.0)$ & 0.460 \\
\hline Cestodes & $10(38.5)$ & $533.3)$ & 0.507 \\
\hline
\end{tabular}

Table 3: Prevalence of intestinal parasitic infection by season in Rattus rattus trapped from Khan Younis an Jabalia in Gaza Strip $(n=41)$

\begin{tabular}{|c|c|c|c|c|c|}
\hline Intestinal parasites class & Summer & Autumn & Winter & Spring & P-value \\
\hline Protozoa & $3(21.4)$ & $4(80.0)$ & $2(22.2)$ & $3(23.1)$ & 0.069 \\
\hline Nematodes & $3(21.4)$ & $2(40)$ & $3(33.3)$ & $2(15.4)$ & 0.639 \\
\hline Cestodes & $2(14.3)$ & $3(60)$ & $4(44.4)$ & $6(46.2)$ & 0.177 \\
\hline
\end{tabular}

Table 4: Occurrence of double, triple infection in Rattus rattus

\begin{tabular}{|c|c|c|}
\hline Double/triple infection & No. of positive & $\%$ \\
\hline Cestodes + nematode & 6 & 16.2 \\
\hline Cestodes +Ectoparasites & 4 & 10.8 \\
\hline Nematode + protozoa & 4 & 10.8 \\
\hline Cestodes + protozoa & 5 & 13.5 \\
\hline Cestodes + nematode + protozoa & 2 & 5.4 \\
\hline
\end{tabular}


Table 5: Prevalence of protozoa, nematodes, cestodes and ectoparasites in Rattus rattus collected from Khan Younis and Jabalia in Gaza Strip

\begin{tabular}{|l|c|c|}
\hline \multicolumn{1}{|c|}{ Parasites recovered } & Number & Percentage \\
\hline Protozoa & $\cdot$ & \\
\hline Giardia lamblia & 6 & 14.6 \\
\hline E. histolytica/dispar & 7 & 17.1 \\
\hline Isospora belli & 4 & 9.8 \\
\hline Acanthocephalan & 1 & 2.4 \\
\hline Nematodes & 10 & 24.4 \\
\hline Syphacia obvelata & 6 & 20 \\
\hline Heligmonoides josephi & 3 & 10 \\
\hline Strongyloides egg & 1 & 2.4 \\
\hline Cestodes & & \\
\hline Hymenolepis diminuta & 15 & 36.6 \\
\hline Ectoparasites & 10 & 24.4 \\
\hline Xenopsylla cheopis & 7 & 17.1 \\
\hline Polyplax spinulosa & 3 & 7.3 \\
\hline
\end{tabular}

\section{Discussion}

Rodents normally live in close contact to human and play a significant role in human health, welfare and economy. Also a rodent harbors different types of parasites in the intestines, lung, blood and tissue. Ectoparasites constitute a dangerous factor in transmitting pathogenic microorganisms and reservoir hosts for parasitic zoonosis. Gaza Strip suffers from different health problems including of contamination of environment, spreading of garbage, rodents from different types. According to Abd Rabou et al. (2007) two types of rats present in Wadi Gaza, Rattus rattus and Rattus norvegicus. The overall prevalence of intestinal parasites in $R$. rattus from Gaza was 56.8\%. Different studies haves reported a wide range of prevalence, Seo et al, (1964) in Korea reported a prevalence of $93.4 \%$ among house rats. Paramasraran et al. (2005) in Malaysia reported $41 \%$.

In the present study, the nematodes recovered represented $27.02 \%$ while Stojcevic et al. (2004) in Croatia recorded a prevalence of $65.1 \%$. The seasonal disruptions of intestinal parasites of rats indicated that Cestodes were high in winter than either protozoa or nematodes; same prevalence of protozoa and nematodes was $8.1 \%$ in summer season. Also, similar prevalence for nematodes and Cestodes was in autumn season. This may be explained by the fact that the majority of nematodes need the soil to complete the life cycle and the environmental conditions (Pechova and Foltan, 2008). The low prevalence of all cestodes, nematodes and protozoa was observed $(2.7 \%)$ in 
winter. This result agreed with Vincent and Font (2003).

In the present study, 21 out of 26 $(80.7 \%)$ were capable to transmit more than one parasite in the same host. So, the double and sometimes triple infection or more were noticeable in the rats. This fact agreed with many authors (Morsy et al, 1995; El-Shahawi et al, 2010).

In the present study, isolated protozoa were E.histolytica/dispar (18.9\%) and Giardia lamblia (16.2\%) and Isospora belli $(10.8 \%)$ which were found in the stool of the examined rats. These are known zoonotic potential in Gaza Strip and risky to human (Hussein, 2011).

In the present study, $H$. diminuta was the only cestodes isolated $15 / 15$ $(100 \%)$. In Croatia $36.9 \%$ were reported (Stojcevic et al, 2004), in Kuwait $5.59 \%$ (Al-Behbehani, 2002) and in Egypt zoonotic hymenolepiasis were reported (Massoud et al, 2007; AbdelGhaffar et al, 2011). S. obvelata $(20 \%)$ and $H$. josephi $(10 \%)$ were the most common nematodes. Al-Behbehani, (2002) reported a rate of $S$. obvelata (12.75\%) and H. Josephi (5.27\%).

In the present study, 10/41 (24.4\%) rats were found infected by two ectoparasites, lice and fleas. In Croatia, $P$. spinulosa (14.5\%) were reported on rodents (Stojcevic et al, 2004).

In Egypt, Xenopsylla cheopis, vector of plague, were reported $(57.7 \%)$ on rodents in Menoufia Governorate (Bakr et al, 1996), also Mikhail et al. (2009) and El-Bahnasawy et al. (2012) reported the wide distribution of $X$. cheopis and other species of fleas in many of the Egyptian governorates.

In the present study, Moniformis moniliformis was the only acanthacephalan isolated for the first time in Gaza strip. Zoonotic M. moniliformis was reported in a 2-year-old girl in Iran (Salehabadi et al, 2008). Arizono et al. (2012) in Japan identified the acanthocephalan in the human small intestine.

Moniliformis and Macracanthorhyncus are two genera that cause the zoonotic acanthocephaliasis. Both the helminthes are considered as perforating since they may cause intestinal perforation in their final hosts, which can be facilitated by the worm's proteolytic enzymes. Wide range of mammals including rats is susceptible to acquire $M$. moniliformis as definitive hosts. Rats with their cosmopolitan distribution, not only threatening different aspects of public health generally but also are known to carry several zoonotic parasites even in developed countries (Battersby et al, 2002).

\section{Conclusion}

In spite the efforts done by Gaza strip municipalities the presence of huge quantities of garbage especially in the time of blockade on Gaza strip, and a big numbers of stray cats, the rodents still constitute a health problem and a risk for human in transmission of diseases. It is concluded that the black rat was infected with intestinal parasites \& ectoparasites where $H$. diminuta was the commonest type of the isolated cestodes. The black rat was a mechanical carrier for Giardia lamblia and E. histolytica/dispar. 
Generally speaking, the wild or dohuman welfare. Zoonoses are diseases naturally transmissible between vertebrate animals and man including those transmitted by the direct contact with the infected animals or carcasses, by food or water contamination, and by inhalation of infected dust. The intestinal parasites in rodents in Gaza strip are risky. The awareness from rodents and their zoonotic parasites is must.

The Health and Veterinary Authorities must take into consideration rodent control by environmental friend rodenticides mainly in Khan Younis and Jabalia, Gaza Strip.

\section{References}

Abd El-Halim, AS, Allam, KA, Metwally, AM, EI Boraey, AM, 2009: Seasonal variation of infestation rate with lice, tick and mite among rodents in certain Egyptian regions. J. Egypt. Soc. Parasitol. 39, 2:617-24.

Abd Rabou, A, Yassin, M, Al Agha, M, Hamad, D, Ali, A, 2007: Wild ma mmals in the Gaza Strip, with particular reference to Wadi Gaza. Islamic Univ. J. 1726-6807:87-109.

Abdel-Ghaffar, F, Semmler, M, AlRasheid, KA, Strassen, B, Fischer, $\mathbf{K}$, et al, 2011: The effects of different plant extracts on intestinal cestodes and on trematodes. Parasitol. Res. 108, 4: 979-84.

Al-Behbehani, B, 2002: Studies on helminthes infecting some local fishes in Kuwait. J. Egypt. Soc. Parasitol. 32, 3:879-92. mestic rodents play a risky role in the Anderson, R, Willmott, S, Chabaud, A, 2009: Keys to the nematode parasite of vertebrate: Reservoirs of parasites in India. Integrative Zool. 3, 1:21-6

Angel, A, Wanless, RM, Cooper, J, 2009: Review of impacts of the introduced house mouse on islands in the Southern Ocean: are mice equivalent to rats? Biol. Invasions 11:1743-54.

Arizono, N, Kuramochi, T, Kagei, N, 2012: Molecular and histological identification of the acanthocephalan Bolbosoma cf. capitatum from the human small intestine. Parasitol. Int. 61, 4: 715-8.

Atkinson, I, 1989: Introduced animals and extinctions. In: D. Western and M. Pearl (eds), Conservation for the Twenty-first Century. Oxford University Press, New York.

Bakr, M, Morsy, TA, Nassef, N, ElMeligi, M, 1996: Flea ectoparasites of commensal rodents in Shebin El-Kom, Menoufia Governorate, Egypt. Shebin El-Kom, Egypt. J. Egypt. Soc. Parasitol. 26, 1:39-52.

Battersby, SA, Parsons, R, Webster, JP, 2002: Urban rat infestations and the risk to public health In: United Kingdom: Chadwick House Publishing. London.

Claveria, FG, Causapin, J, Guzman, MA, Toledo, MG, Salibay, C, 2005: Parasite biodiversity in Rattus spp. caught in wet markets. Southeast Asian J. Trop. Med. Pub. Hlth. 36, 14:146-8.

El-Bahnasawy, MM, Ahmad, GMS, Abdel-Fattah, MA, Gaber, WAI, 
Morsy, TA, 2012: Is plague a problem in the Egyptians returning back from Libya? J. Egypt. Soc. Parasitol. 42, 2: 329-48.

El-Shahawi, GA, Abdel-Latif, M, Saad, AH, Bahgat, M, 2010: Setaria equina: In vivo effect of diethylcarbamazine citrate on the microfilariae in the Albino rats. Exp. Parasitol. 126, 4:603-10.

Hoogstraal, H, 1958: Notes on African Haemaphysalis ticks. IV. Description of Egyptian populations of the yellow dogtick, H. leachii leachii (Audouin, 1827) (Ixodoidea, Ixodidae). J. Parasitol. 44, 5:548-58.

Hoogstraal, H, 1965: The flea (Siphonaptera) of Egypt: Host-parasite relationships of cricetid rodents (Family Spalacidae, Muridae, Gliridae, Dipodidae and Hystricidae). J. Egypt. Pub. Hlth. Assoc. 41: 343-79.

Hussein, AS, 2011: Prevalence of intestinal parasites among school children in northern districts of West Bank-Palestine. Trop. Med. Int. Hlth. $16,2: 240-4$

Jones, A, Bray, RA, Khalil, LF, 1994: Keys to the cestode parasites of vertebrates, CABI. ISBN 0-85198-8792.

Luke，HC，Keith-Roach， E， 1922: The Handbook of Palestine, Issued under the Authority of the Government of Palestine, Macmillan and Co., limited. Martin's Street, London, http:// www. archive.org/details/handbookofpalest00 lukeuoft.
Massoud, AM, Shazly, AM, Shahat, SA, Morsy, TA, 2007: Mirazid in treatment of human hymenolepiasis. J. Egypt. Soc. Parasitol. 37, 3:863-76.

Mazyad, SA, Morsy, TA, Fekry, AA, Farrag, AM, 1999: Mites infesting two migratory birds, Coturnix c. coturnix (quail or Simmaan) and Sturnus $v$. vulgaris (starling or zarzuur) with reference to avian zoonosis. J. Egypt. Soc. Parasitol. 29, 3:745-61.

Mikhail, MW, Al-Bursheed, Kh M, AbdEl-Halim, AS, Morsy, TA, 2009: Studies on mosquito borne diseases in Egypt and Qatar. J. Egypt. Soc. Parasitol. 39, 3:745-56.

Morsy, TA, 2012: Insect bites and what is eating you? J. Egypt. Soc. Parasitol. 42, 2:291-308.

Morsy, TA, Fayad, ME, Abou Shady, MK, Yousef, NS, 1986: Ectoparasites of rodents in Suez Governorate with special reference to fleas. J. Egypt. Soc. Parasitol. 16, 2:457-68.

Morsy, TA, Naser, AM, el Gibali, M R, Anwar, AM, el Said, AM, 1995: Studies on zoonotic cutaneous leishmaniasis among a group of temporary workers in North Sinai Governorate, Egypt. J. Egypt. Soc. Parasitol. 25, 1: 99-106.

Morsy, TA, Shoukry, A, El Kady, G A, 1988: A review and distribution map of rodents in Sinai, Egypt. J. Egypt. Soc. Parasitol. 18, 2:683-92.

Mosabah, AAA, Morsy, TA, 2012: 
Tick paralysis: First zoonosis record in Egypt. J. Egypt. Soc. Parasitol. 42, 1: 71-8.

Nama, HS, Parihar, A, 1976: Quantitative and qualitative analysis of helminth fauna in Rattus rattus rufescens. J. Helminthol. 50, 2:99-102.

Paramasvaran, S, Krishnasamy, M, Lee, HL, John, J, Lokman, H, 2005: Helminthes infections in small mammals from Ulu Gombak Forest Reserve and the risk to human health. Trop. Biomed. 22, 2:191-4.

Pechova, H, Foltan, P, 2008: The parasitic nematode Phasmarhabditis hermaphrodita defends its slug host from being predated or scavenged by manipulating host spatial behaviour. Behav. Processes 78, 3:416-20. Rayyan, A, Al-Zain, B, Al-Hindi, A, 2013: Gastrointestinal parasites of the Rock-tail Rock Agama, Laudakia stellio from Gaza Strip, Palestine. J. Biol. 1, 2:39-41.

Russell, JC, Clout, MN, 2004: Modeling the distribution and interaction of introduced rodents on New Zealand off shore islands. Global Econ. Biogeogr. 13:497-507.

Salehabadi, A, Mowlavi, G, Sadjjadi, SM, 2008: Human Infection with Moniliformis moniliformis (Bremser 1811) (Travassos 1915) in Iran: Another case report after three decades. Vector-Borne Zoon. Dis. 8, 1:101-3.

Seo, B, Rim, H, Lee, C, Yoon, T, 1964: Studies on the parasitic helminthes of Korea II parasitic of the rat, Rattus norvegicus in Soul, with the description of Capillaria hepatica. Korean J. Parasitol. 2, 1:55-62.

Singla, LD, Singla, N, Parshad, VR, Juyal, PD, Naresh, K S, 2008: Rodents as Reservoirs of Parasites in India. Integrative Zool. 3, 1:21-6.

Stojcevic, D, Mihaljevic, Z, Marinculic, A, 2004: Parasitological survey of rats in rural regions of Croatia. University of Zagreb, Croatia, Original Paper, 49:70-4.

Towns, DR, 2009: Rodents. In: Encyclopedia; Gillespie, RG, and Clague, DA, (Eds.).

Towns, DR, Atkinson, IAE, Daugherty, CH, 2006: Have the harmful effects of introduced rats on islands been exaggerated? Biol. Invasions 8:863-91.

Vincent, AG, Font, WF, 2003: Seasonal and yearly population dynamics of two exotic helminths, Camallanus coti (Nematoda) and Bothriocephalus acheilognathi (Cestoda), parasitizing exotic fishes in Waianu Stream, O'ahu, Hawaii. J. Parasitol. 89, 4:756-60

WHO, 1994: Bench Aids for the Diagnosis of Intestinal Helminthes.WHO/ CDS/Geneva.

Yom-Tov, YS, Yom-Tov, Moller, H, 1999: Competition, coexistence, and adaptation amongst rodent invaders to Pacific and New Zealand Islands. J. Biogeogr. 26:947-58.

Younis, TA, Fayad, ME, el Hariry, MA, Morsy, TA, 1995: Interaction between acari-ectoparasites and rodents in Suez Governorate, Egypt. J. Egypt. Soc. Parasitol. 25, 2:377-94. 


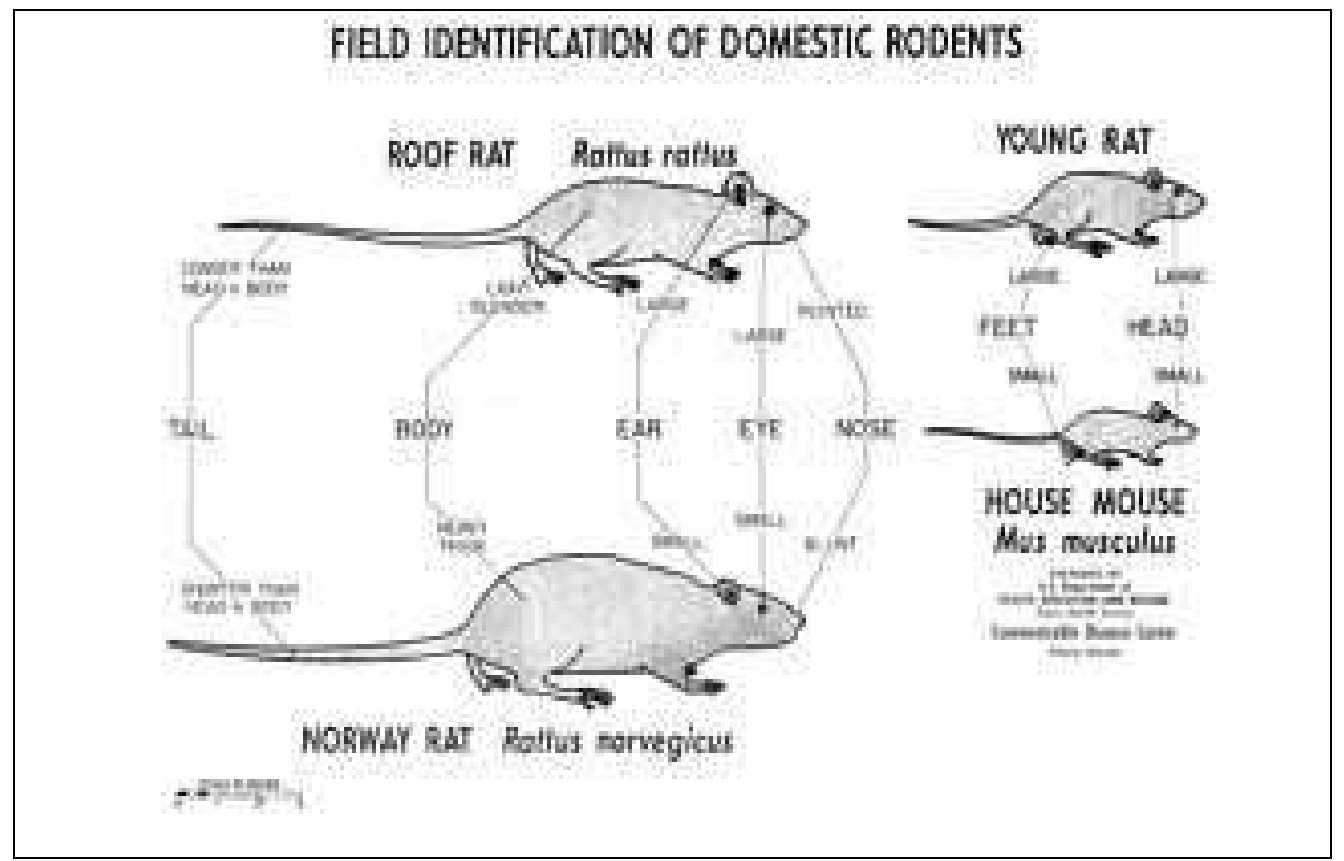

\section{Explanation of figures}

F. 1: A trap was used for trapping rats

F. 2:E. histolyticaldispar trophozoite

F. 3: G. lamblia trophozoite

F. 4: Isospora

F. 5: Scolex of $H$ diminuta

F. 6: mature prolottids $H$. diminuta

F. 7: egg of H. diminuta

F. 8: Moniformis moniliformis egg

F. 9: Syphacia obvelata (male)

F. 10: Heligmonoides josephi female

F. 11: Strongyloides type egg

F. 12: Xenopsylla cheopis female

F. 13: Xenopsylla cheopis male

F. 14: Polyplax spinulosa male

F. 15: Polyplax spinulosa female 

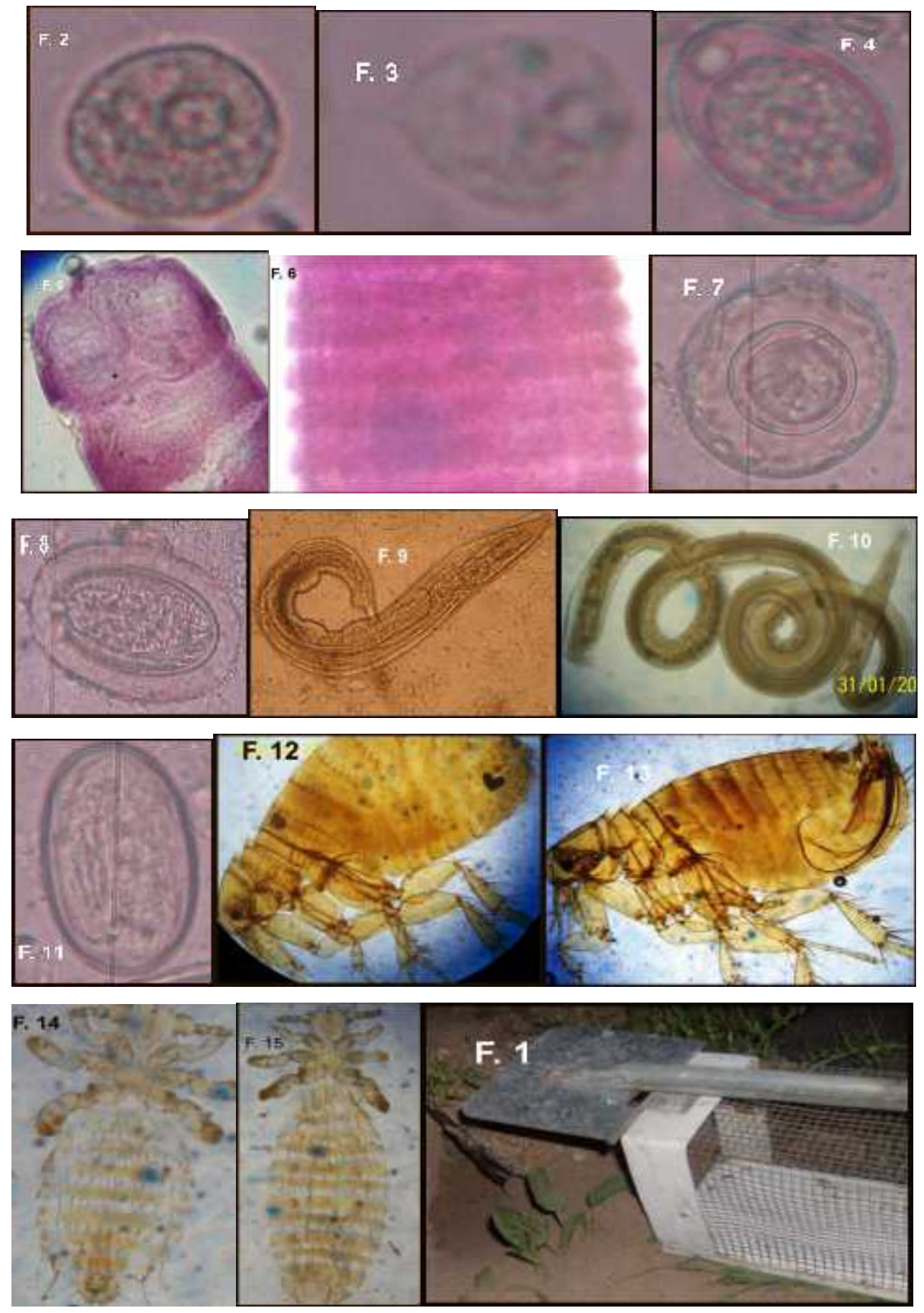